\title{
PENGARUH KARIR, LINGKUNGAN KERJA, MOTIVASI, DAN KEPEMIMPINAN TERHADAP KINERJA PEGAWAI DI PUSAT INFORMASI PENGAWASAN BADAN PENGAWASAN KEUANGAN DAN PEMBANGUNAN
}

\author{
Ramlan \\ Fakultas Ekonomi Universitas Pakuan \\ Email: ramlanbogor@gmail.com
}

\section{ARTICLE INFO}

Article History

Received 23 Dec 2018

Revised 10 January 2019

Accepted 31 January 2019

\section{JEL Classification}

$\mathrm{O} 15$

Kata kunci:

Karir,

Lingkungan kerja,

Motivasi,

Kepemimpinan, dan

Kinerja Karyawan

\begin{abstract}
ABSTRAK
Studi ini akan mengukur kinerja pegawai berdasarkan beberapa variable independen. Penelitian ini dilakukan di Pusat Informasi Pengawasan Badan Pengawasan Keuangan dan Pembangunan dengan menggunakan metode kuantitatif dengan survey pada 120 responden yang diambil secara random sampling. Hasil analisis data dari SPSS menggambarkan korelasi dari variable-variabel tersebut untuk mengungkap tujuan dari hasil penelitian ini yaitu untuk mengukur seberapa jauh pengaruh secara bersama-sama antara variabel Karir $\left(X_{j}\right)$, Lingkungan Kerja $\left(X_{2}\right)$, Motivasi $\left(X_{3}\right)$ dan Kepemimpinan $\left(X_{4}\right)$ dengan variabel Kinerja Pegawai pada Pusat Informasi Pengawasan BPKP (Y). Keempat variable tersebut terbukti berpengaruh terhadap kinerja pegawai.
\end{abstract}

\section{PENDAHULUAN}

Dalam kehidupan modern saat ini organisasi dipandang sebagai salah satu ciri bentuk kehidupan di mana manusia menempatkannya secara fungsional sebagai alat untuk mencapai tujuan. Selain itu, organisasi merupakan bentuk wadah kerjasama dan wahana untuk mencapai tujuan yang diharapkan agar segera menjadi kenyataan. Di dalam suatu organisasi, sumber daya manusia merupakan faktor yang memegang peranan utama. Sumber daya dalam organisasi pada hakekatnya adalah pegawai sedangkan faktor-faktor lain seperti alat-alat produksi dan teknologi merupakan hasil karya manusia. Semua itu akan memberi hasil jika pegawai sebagai faktor utama dalam organisasi dapat memanfaatkan alat-alat produksi dan teknologi tersebut dengan seefektif mungkin.
Mengingat sentralnya posisi manusia dalam faktor kehidupan maka faktor manusia itu pada setiap level organisasi perlu diperlakukan secara benar. Artinya pendayagunaan sumber daya manusia itu disamping dipandang sebagai alat organisasi disatu pihak, juga harus mengingat dan memperhatikan harkat dan martabat manusia di pihak lain. Untuk menggunakan sumber daya manusia sebagai keunggulan dalam suatu organisasi maka tantangan yang ada dalam setiap organisasi adalah memastikan bahwa organisasi telah memiliki sumber daya manusia yang berkualitas serta mempunyai potensi tinggi sehingga organisasi tidak harus rnerasa sangat khawatir akan adanya perubahan yang terjadi dilingkungan faajanya. Dengan kata lain bahwa sumber daya manusia adalah faktor yang sangat penting bagi keberhasilan suatu organisasi. 
Kepemimpinan mempunyai pengaruh ketika dipergunakan oleh pemimpin dalam kepemimpinannya, yaitu proses interaksi dengan para pegawainya. Oleh karena itu dapat dikatakan bahwa pada hakekatnya kepemimpinan adalah gaya yang menonjolkan penampilan sebagai seorang pemimpin. Seorang pemimpin dapat berubah-ubah serta amat bergantung kepada pegawainya dan situasi yang dihadapinya, kepemimpinan cenderung berbeda-beda dari satu situasi kesituasi lainnya, oleh karena itu penting bagi pimpinan untuk selalu mendiagnosa perilakunya.

Untuk menyiapkan, menempatkan secara tepat serta mengembangkan sumber daya manusia dalam sebuah organisasi merupakan masalah yang krusial. Hal ini bertujuan memadukan dan menyelaraskan kepentingan organisasi dengan kepentingan pegawai.

Masalah lain yang tidak kalah pentingnya yaitu membuat lingkungan kerja agar pegawai merasa senang bekerja dalam suatu organisasi seperti gaya kepemimpinan yang baik, komunikasi yang searah antara pimpinan dengan para pegawainya, selain itu juga diperlukan adanya dorongan atau motivasi bagi pegawai.

Motivasi sangat penting dan dibutuhkan setiap orang dalam melaksanakan pekerjaanya, karena motivasi adalah kondisi yang dapat menggerakkan pegawai agar mampu mencapai tujuan dari motifnya (dorongan kebutuhan dalam diri pegawai yang perlu dipenuhi agar pegawai tersebut dapat menyesuaikan diri terhadap lingkungannya). Jadi jelas bahwa seorang pegawai harus memiliki motivasi yang tinggi agar dapat mencapai tujuan dari motifnya dengan mudah. Berkaitan dengan motivasi, maka ada beberapa kebutuhan yang harus terpenuhi antara lain kebutuhan fisiologis, kebutuhan rasa aman, kebutuhan untuk dapat diterima oleh kelompoknya, kebutuhan akan harga diri, kebutuhan untuk menggunakan kemampuannya, ide-ide atau pendapatnya.
Lingkungan kerja yang nyaman, rasa aman, dan tentram, akan membuat manusia mampu melaksanakan kegiatannya dengan baik, sehingga dicapai suatu hasil yang optimal, apabila diantaranya ditunjang oleh suatu kondisi lingkungan yang sesuai. Suatu kondisi lingkungan dikatakan baik atau sesuai apabila manusia dapat melaksanakan kegiatannya secara optimal, sehat, aman dan nyaman. Ketidak sesuaian lingkungan kerja dapat dilihat akibatnya jangka waktu yang lama. Lebih jauh lagi, keadaan lingkungan yang kurang baik dapat menuntut tenaga dan yang lebih banyak dan tidak mendukung diperolehnya rancangan kerja efisien.

Selain kepemimpinan, motivasi dan lingkungan kerja, jenjang karir mempunyai peran penting yang bisa meningkatkan kinerja pegawai, arier sebagai serangkaian kegiatan pekerjaan yang terpisah tetapi ada hubungannya, yang memberi kelangsungan, kedudukan dan arti riwayat hidup sesorang atau sebagai serangkaian jabatan atau pekerjaan yang dipegang oleh seseorang selama jangka waktu yang relative lama, biasanya lima tahun atau lebih.

Penelitian ini dilaksanakan di Badan Pusat Informasi Pengawasan yang merupakan salah satu unit organisasi di lingkungan Badan Pengawasan Keuangan dan Pembangunan (BPKP). Berkedudukan diibu kota Negara Republik Indonesia Jakarta, Badan Pusat Informasi dan Pengawasan merupakan unit kerja setingkat eselon II dengan Visinya, "Menjadi Penyaji Informasi yang Andal dan Agen Perubahan Melalui Dukungan Teknologi Informasi". Untuk itu, pegawai dituntut meningkatkan prestasi kerja agar dapat mewujutkan visi tersebut, sehingga tujuan dari hasil penelitian ini adalah untuk mengetahui pengaruh variabel karir, lingkungan kerja, motivasi dan kepemimpinan dengan variabel kinerja pegawai. 
TINJAUAN PUSTAKA DAN PENGEMBANGAN HIPOTESIS

\section{Manajemen Sumber Daya Manusia}

Sumber daya manusia dapat dilihat dari dua aspek yakni kuantitas dan kualitas. Kuantitas menyangkut jumlah sumber daya manusia (penduduk) yang kurang penting konstribusinya dalam pembangunan dibandingan dengan aspek kualitas bahkan kuantitas sumber daya manusia tanpa disertai dengan kualitas yang baik akan menjadi beban pembangunan suatu bangsa, sedangkan kualitas menyangkut mutu sumber daya manusia tersebut yang menyangkut kemampuan, baik kemampuan fisik maupun kemampuan non isik (kecerdasan dan mental).

Sunyoto (2005) menjelaskan bahwa Manajemen Sumber Daya Manusia merupakan serangkaian tindakan dalam hal penarikan, seleksi, pengembangan. pemeliharaan dan penggunaan sumber daya manusia, bukan sumber daya lainnya, untuk mencapai tujuan baik tujuan individu maupun organisasi. Menurut Hasibuan (2000) Manajemen Sumber Daya Manusia diartikan sebagai ilmu dan seni mengatur hubungan dan peranan tenaga kerja agar efektif dan efisien membantu terwujudnya tujuan perusahaan, karyawan dan masyarakat dengan melakukan fungsifungsinya yang terdiri dan perencanaan, pengorganisasian, pengarahan, pengendalian, pengadaan, pengembangan, konpensasi, pengintegrasian, pemelihararaan, kedisiplinan, dan pemberhentian".

Berdasarkan pendapat para ahli diatas menunjukkan bahwa Manajemen Sumber Daya Manusia merupakan seni dan ilmu dalam perencanaan, pengorganisasian, pengarahan, dan pengawasan dari pengadaan, pengembangan, pemberian kompensasi, pengintegrasian dan pemeliharaan sumber daya manusia untuk memperoleh dan memanfaatkan sumber daya manusia semaksimal mungkin sehingga tercapai tujuan tertentu dalam organisasi. tanpa mengesampingkan tujuan yang hendak dicapai para anggotanya.

\section{Kinerja Pegawai}

Buchari Zainun (1981) kinerja pada dasamya mencakup sikap mental dan perilaku yang selalu mempunyai pandangan bahwa pekerjaan yang dilaksanakan saat ini harus lebih berkualitas dibanding hasil kerja pada masa lalu dan pekerjaan untuk masa yang akan datang harus lebih berkualitas dibanding hasil kerja pada saat ini. Menurut John Soeprihanto (1995) kinerja kerja pegawai adalah kemampuan seperangkat sumber-sumber ekonomi untuk menghasilkan sesuatu atau diartikan juga sebagai perbandingan atau pengorbanan.

Jika membicarakan masalah kinerja maka muncul suatu situasi yang paradoksial (bertentangan) karena belum ada kesepakatan umum tentang maksud pengertian kinerja dengan kriterianya dalam mengukur petunjukpetunjuk mengenai Kinerja Pegawai. Selain itu, tidak ada konsepsi, metode penerapan maupun cara pengukuran yang bebas dari kritik. Secara umum kinerja diartikan sebagai hubungan antara hasil maupun fisik dengan masukan yang sebenarnya. Kinerja juga diartikan sebagai tingkatan efisiensi dalam memproduksi barang-barang atau jasa-jasa "kinerja" mengutamakan cara pemanfaatan secara baik terhadap sumber-sumber dalam memproduksi barang-barang.

Karir

Moekidjat (1994) menjelaskan bahwa karir merupakan suatu bidang studi yang penting dalam perilaku organisasi dan dewasa ini telah diakui mempunyai hubungan yang erat dengan praktik manajemen sumber daya manusia, bahkan diramalkan akan menjadi lebih penting pada masa yang akan datang mengingat situasi sosial yang berubah dengan cepat. Menurut Flippo (1991) mengemukakan bahwa karir sebagai serangkaian kegiatan pekerjaan yang terpisah tetapi yang ada 
hubungannya, yang memberikan kelangsungan, kedudukan dan arti dalam riwayat hidup seseorang.

Dengan demikian yang dimaksud karir adalah serangkaian pengalaman pekerjaan yang berurutan dan menuju ke tingkat tanggung jawab, status, wewenang dan pengkaryaan yang lebih besar. Suatu susunan kerja yang mendukung terjadinya suatu dinamika karir yang positif akan sangat mempengaruhi kondisi pegawai secara moral maupun material. Oleh karena itu, kepentingan ini dipandang organisasi sebagai kepentingan yang berdimensi ekonomis dan sosial, perhatian terhadap masalah ini dalam berapapun kadarnya akan memberi konsekuensi bagi organisasi itu sendiri maupun bagi individu. Permasalahan karir merupakan masalah hubungan timbal balik antara organisasi dengan individu pegawai.

\section{Lingkungan Kerja}

Sedamayanti (1996) mengemukakan lingkungan kerja adalah keseluruhan alat perkakas dan bahan yang dihadapi, lingkungan sekitar dimana seseorang bekerja, metode kerjanya, serta pengaturan kerjanya baik sebagai perorangan maupun sebagai kelompok. Menurut Ahyari (1994) menjelaskan lingkungan kerja adalah lingkungan di mana ada pegawai melaksanakan tugas dan pekerjaannya sehari-hari.

Dari keterangan diatas dapat disimpulkan bahwa pada dasarnya lingkungan kerja adalah segala yang ada di sekitar pegawai yang dapat mempengaruhinya dalam menjalankan tugas serta turut berpengaruh dalam mempengaruhi kepuasan kerja seseorang. Adapun faktor-faktor yang mempengaruhi lingkungan kerja mencakup pengendalian suara bising, pengaturan penerangan di tempat kerja, penggunaan suhu udara, pelayanan kebutuhan pegawai, penggunaan warna, pemeliharaan kebersihan lingkungan kerja dan penyediaan fasilitas yang dibutuhkan pegawai, seperti kamar mandi, ruang ganti pakaian, dan lain sebagainya (Tulus, 1993).

\section{Motivasi Kerja}

Motivasi merupakan kegiatan yang mengakibatkan, menyalurkan, dan memelihara dan memelihara perilaku manusia. Untuk itu rnaanajer harus memahami perilaku bawahannya agar dapat mempengaruhi untuk bekerja dengan lebih baik secara efektif dan efesien sesuai dengan harapan tujuan organisasi / lembaga.

Menurut pendapat beberapa para ahli memberikan definisi motivasi sebagai berikut:

Motivation refers of degree of readiness of an organization to pursee same designated goal ang implier the determination of the nature and lacas of the foreces inducing the degree of readiness (Barnes, 1996)

Motivasi adalah kekuatan yang mengendalikan dan menggerakkan seseorang untuk melakukan tindakan atau perilaku yang diarahkan pada tujuan tertentu (Marwansah, 1999)

Berdasarkan beberapa pengertian di atas, maka yang dimaksud dengan motivasi adalah kemampuan dan keinginan yang terdapat pada diri individu yang mendorongnya untuk melakukan pekerjaan, tindakan-tindakan kegiatan atau sesuatu yang menjadi dasar atau alas an mengapa seseorang berperilaku atau dengan kata lain motivasi adalah kemauan dan keinginan yang terdapat pada diri seseorang karyawan yang mendorongnya untuk melakukab upaya peningkatan kualitas pelaksanaan pekerjaan atau kegiatan-kegiatan dalam rangka mencapai tujuan secara efektif dan efesien.

\section{Kepemimpinan}

Kepemimpinan mempunyai fungsi untuk memandu, menuntun, memberi atau membangkitkan motivasi kerja, mengemudikan organisasi, menjalin jaringan komunikasi yang baik dan membawa para 
pengikutnya kepada sasaran yang ingin dituju, sesuai dengan ketentuan waktu dan perencanaan. Menurut Nasution (2000) mengemukakan bahwa kepemimpinan adalah suatu usaha untuk mempengaruhi orang per orang, lewat komunikasi untuk dapat mencapai satu atau beberapa tujuan. Hasibuan (2000) menyatakan kepemimpinan adalah cara seseorang pemimpin mempengaruhi perilaku bawahan, agar mau bekerja secara produktif untuk mencapai tujuan organisasi.

Dari beberapa definisi kepemimpinan seperti yang dikemukakan di atas, dapat ditarik suatu kesimpulan tentang definisi kepemimpinanm yaitu kepemimpinan adalah suatu kemampuan yang dimiliki oleh seseorang (pemimpin) dalam upaya mempengaruhi orang lain/kelompok lain agar mau berfikir dan atau berperilaku/bertindak dan atau bekerja bersama-sama untuk mencapai suatu tujuan tertentu.

\section{Pengembangan Hipotesis}

Seluruh kegiatan penelitian mulai dari perencanaan, pelaksanaan, sampai dengan penyelesaiannya harus merupakan kesatuan atau pemikiran yang utuh menuju pada tujuan tunggal yakni memberikan jawaban tunggal atas pertanyaan-pertanyaan yang diajukan dalam perumusan masalah. Kerangka pemikiran menunjukkan skema yang menjelaskan hubungan antar variabel dalam penelitian

Dalam sebuah organisasi, kemandirian pegawai harus mendapatkan perhatian yang serius. Pegawai yang memiliki lingkungan kerja untuk mandiri akan berusaha melaksanakan tugas yang menjadi tanggung jawabnya dengan baik. Sebaliknya, pegawai yang tidak memiliki lingkungan kerja untuk mandiri tidak dapat melaksanakan apa yang menjadi tugasnya dengan baik, sehingga dapat merugikan dirinya karena pencapaian kemandirian menjadi terhambat. Oleh karena itu organisasi harus memperhatikan hal-hal yang dapat mempengaruhi kemandirian para pegawainya diantaranya Karir, Lingkungan Kerja, Motivasi, Kepemimpinan.

H1: Terdapat hubungan antara karir dan kinerja pegawai

$\mathrm{H} 1$ : Terdapat hubungan antara lingkungan kerja dan kinerja pegawai

H1: Terdapat hubungan antara motivasi dan kinerja pegawai

$\mathrm{H} 1$ : Terdapat hubungan antara karir dan kinerja pegawai

$\mathrm{H} 1$ : Terdapat hubungan antara kepemimpinan dan kinerja pegawai

\section{METODE PENELITIAN}

\section{Teknik Pengumpulan Data}

Guna mendapatkan data-data yang dibutuhkan dalam penelitian tentunya dibutuhkan teknik-teknik. Penulis dalam teknik pengumpulan data rnenggunakan dua cara, yaitu 1) data primer berupa wawancara, kuisioner, dan observasi; dan 2) sekunder berupa studi literatur yang ada di Pusat Informasi Pengawasan BPKP baik itu berbentuk annual raport maupun jurnal yang ada.

\section{Teknik Pengambilan Sampel}

Teknik pengambilan sample yang dipakai dalam penelitian ini penulis rnenggunakan probability sampling dengan Proportionate Stratifed Random Sampling. Jumlah populasi 120 orang, di mana sampel yang ada diambil secara acak dalam strata yang ada dianggap sebagai sample sesuai proporsi dan professional. Pengambilan sample yang penulis ambil sebanyak 65 orang responden.

Untuk memudahkan dalam perhitungan statistic yang ada, data-data diberikan skala pengukuran dengan memberikan lambang angka, dari angket yang digunakan yaitu rnenggunakan skala penelitian model Likert. Skala Likert ini adalah untuk mengukur sikap responden terhadap suatu obyek yang diteliti. Untuk mengetahui nilai dari ketiga instrument penelitian ini mempunyai lima kemungkinan 
jawaban dengan pembobotannya dilakukan sebagai berikut:

1. Jika jawaban responden memilih Sangat Setuju bobot 5

2. Jika Jawaban responden memilih Setuju bobot 4

3. Jika jawaban responden memilih Kurang Setuju bobot 3

4. Jika jawaban responden memilih Tidak Setuju bobot 2

5. Jika Jawaban responden memilih Sangat Tidak Setuju bobot 1

\section{Teknik Analisis Data}

Untuk mengetahui pengaruh Karir, Lingkungan Kerja, Motivasi dan Kepemimpinan terhadap Kinerja Pegawai. Penulis terlebih dahulu melakukan: (1) Menetukan Rentang Kriteria (2) Uji Validitas dan reabilitas serta pengolahan (analisis) dat untuk lebih jelas sebagai berikut:

1. Menetukan Rentang Kriteria

Setelah skor masing-masing pernyataan diperoleh, maka selanjutnya penghitungan rentang skalanya dengan rumus berikut ini (Singarimbun, dkk. 2001):

$$
\mathrm{RS}=\frac{\mathrm{N}(\mathrm{m}-1)}{\mathrm{m}}
$$

Dimana:

RS = Rentang Skala

$\mathrm{N}$ = Jumlah Sample

$\mathrm{m}$ = Jumlah alternative jawaban tiap kriteria

Dari Rentang Skala dapat diketahui dan diambil kesimpulan mengenai Karir, Lingkungan Kerja, Motivasi dan Kepemimipinan terhadap Kinerja pegawai.

2. Menetukan skala penilaian tiap kriteria

Diperlukan rentang kriteria terendah (Rtr) dan rentang tertinggi (Rtt). Rentang terendah diperoleh dari hasil perkalian antara jumlah sample dengan bobot terendah yaitu 1 Rentang tertinggi adalah hasil perkalian antara jumlah sample dengan bobot tertinggi yaitu 5 . Nilai rentang terendah pada penelitian ini adalah $65 \times 1=$ 65 dan nilai rentang tertingginya adalah 65 $x 5=325$.

Setelah ditentukan rentang kriteria terendah dan tertinggi ditentukan penilaian tiap kriteria.

Rentang 65-125= STS (SangatTidak

Setuju)

Rentang 126-186 = TS (Tidak Setuju)

Rentang 187-247 = KS (Kurang Setuju)

Rentang 248-308 = S (Setuju)

Rentang 309-365 = SS (Sangat Setuju)

Dari skala penilaian di atas dapat diambil kesimpulan mengenai faktor-faktor yang mempengaruhi kinerja pegawai.

\section{Uji Validitas dan Reliabilitas}

Sebelum instrumen penelitian yang berupa kuesioner disebarkan kepada responden, terlebih dahulu diaadakan uji coba. Uji coba dilakukan untuk mengetahui tingkat kehandalan yang memadai dan dikenal dengan istilah validitas. Menurut Mulia Nasution (1995) bahwa "suatu alat ukur dikatakan valid jika alat ukur itu adalah apa yang harus diukur, sedang alat ukur dikatakan reliabel bila mengukur suatu gejala pada waktu berlainan senangtiasa menunjukan hasil yang sama". Jadi dapat dikatakan bahwa validitas berhubungan dengan tingkat konsistensi. Adapun perumusan Uji Validitas dan Reliabilitas sebagai berikut:

a. Validitas

Uji Validitas dasar pengambilan keputusan adalah:

1) Jika $r$ hasil positif serta $r$ hasil $>r_{\text {tabel, }}$ maka butir atau variabel tersebut valid

2) Jika $r_{\text {hasil }}$ tidak positif serta $r_{\text {hasil }}>r_{\text {tabel, }}$ ataupun $r$ hasil negatif $>T$ tabel maka butir atau variabel tersebut tidak valid

b. Reliabilitas 
Uji reliabilitas dasar pengambilan keputusan adalah:

1) Jika $r_{\text {alpha }}$ positif serta $r_{\text {alpha }}>r_{\text {tabel, }}$ maka butir atau variabel tersebut reliabel

2) Jika $r_{\text {alpha }}$ negative dan $r_{\text {alpha }}>r_{\text {tabel, }}$ ataupun $r$ alpha negatif $>r$ tabel maka butir atau variabel tersebut tidak reliabel

Adapun untuk mencari validitas dan reliabilitas intrumen untuk menjaring data kemudian dianalisis dengan komputer program statistical product and service Solution (SPSS) Versi 25 for Windows guna mendapat analisis yang lebih akurat bila dibandingkan manual.

4. Uji Validitas Instrumen

Uji Validitas Content (Validitas isi) penulis akan mengkonsultasikan instrument dengan factor-faktor variabel yang bersangkutan. Uji coba secara empirik menggunakan korelasi produk.

5. Uji Reliabilitas Intrumen

Reliabilitas menunjukan sejauh mana suatu pengukuran dapat -lenghasilkan hasil yang stabil bila dilakukan pengukuran ulang kepada subyek yang sama. Uji Reliabilitas rnenggunakan teknik rumus alpha dan dibantu fasilitas Statistical Product and Service Solution (SPSS) Versi 25 for Windows.

\section{Analisis Koefisien Korelasi}

Tujuan analisis koefisien korelasi dimaksud untuk mengetahui tingkat pengaruh dan signifikan hubungan antara variabel independent $(X)$ terhadap variabel dependen $(\mathrm{Y})$ baik secara persial (masingmasing) maupun simultan (bersama-sama) adapun hasilnya lihat table model summar dan pembahasan
7. Uji Normalitas

Uji normalitas yang dilakukan dengan tujuan untuk mengetahui apakah sebaran data dari variabel Karir, lingkungan kerja dan motivasi terhadap kinerja pegawai berdistribusi normal. Alasan dilakukan uji ini adalah karena pemakaian tehnik analisa korelasi yang akan dipergunakan mensyaratkan dipenuhinya ketentuan data dari variabel yang akan diteliti berdistribusi normal atau mendekati normal. Hal ini sesuai dengan pendapat Ritonga (1997), yaitu "Dalam analisa yang rnenggunakan statistic, distribusi sample harus mengarah berdistribusi normal".

8. Pengujian Hipotesis

Berdasarkan kerangka pemikiran tersebut diatas dapat diajkan hipotesis sebagai berikut: "Variabel Karir (Xi), Lingkungan Kerja (X2) ,Motivas (X3) dan Kepemimpinan $\left(\mathrm{Xj}_{\mathrm{j}}\right)$ berpengaruh signifikan terhadap Kinerja Pegawai (Y)" Untuk membutikan kebenaran dari hipotesis tersebut, maka dilakaukan uji hipotesis, baik uji persial terhadap koefisien regresi terhadap sebagai berikut:

a. Perumusan Hipotesis Penelitian

1) Hipotesis $\mathrm{Nol}\left(\mathrm{H}_{0}\right)$ : tidak terdapat hubungan yang signifikan antara variabel independent yakni Variabel Karir $\left(X_{1}\right)$, Lingkungan Kerja $\left(X_{2}\right)$, Motivasi $\left(X_{3}\right)$ dan Kepemimpinan $\left(X_{4}\right)$ berpengaruh signifikan terhadap Kinerja Pegawai $(\mathrm{Y})<0$.

2) Hipotesis Alternatif $\left(\mathrm{H}_{, \prime}\right)$ : tidak terdapat hubungan yang signifikan antara variabel independent yakni Variabel Karir (X1), Lingkungan Kerja (X2), Motivasi (X3) dan Kepemimpinan (X4) berpengaruh signifikan terhadap Kinerja Pegawai $(\mathrm{Y})>0$.

b. Penentuan nilai kritis

Mengunakan $F_{\text {tabel }}$ dengan tingkat signifikan (a) $5 \%$, derajat kebebasan 
pembilang $k$ dan derajat kebebasab penyebut $n-k-1$

c. Menetukan nilai $F_{\text {tabel }}$ Diketahui dari perhitungan SPSS (tabel Anova pada kolom F)

d. Pengambilan Keputusan/Kesimpulan Keputusan menolak atau menerima hipotesis, dengan ketentuan sebagai berikut: jika nilai $F_{\text {tabel }}>$ nilai $F_{\text {tabel }}$ atau $F$ kritis maka $\mathrm{H}_{0}$ ditolak dan $\mathrm{H}_{\mathrm{a}}$ diterima. Sebaliknya jika nilai $F_{\text {tcst }}<$ nilai Ftabei atau $\mathrm{F}$ kritis maka Ho diterima dan $\mathrm{H}_{\mathrm{a}}$ ditolak.

\section{HASIL DAN PEMBAHASAN}

Uji Validitas dan Reliabilitas

1. Variabel Karir $\left(X_{1}\right)$ Untuk mengetahui hasil analisis dari variabel karir $\left(X_{1}\right)$ dengan menggunakan komputer program Statistical Product and Service Solution (SPSS) Versi 25 for windows input Data Karir $\left(X_{1}\right)$ dengan jumlah soal sebanyak 10 pernyataan, setelah itu dilakukan analisis yang sesuai menghasilkan output untuk Karir $\left(\mathrm{X}_{1}\right)$ dengan hasil yang lebih akurat.

Tabel 1. Item Total Statistics

\begin{tabular}{|c|c|c|c|c|}
\hline & & \multirow{2}{*}{$\begin{array}{l}\text { Scale } \\
\text { Variance } \\
\text { if }\end{array}$} & \multirow{2}{*}{$\begin{array}{l}\text { Corrected } \\
\text { Item-Total }\end{array}$} & Cronbach's \\
\hline & $\begin{array}{l}\text { Scale } \\
\text { Mean if }\end{array}$ & & & $\begin{array}{l}\text { Alpha if } \\
\text { Item }\end{array}$ \\
\hline & $\begin{array}{l}\text { Item } \\
\text { Deleted }\end{array}$ & $\begin{array}{l}\text { Item } \\
\text { Deleted }\end{array}$ & Correlation & Deleted \\
\hline VAR00001 & 55.7077 & 64.116 & 455 & .737 \\
\hline VAR00002 & 55.9692 & 61.562 & .566 & .725 \\
\hline VAR00003 & 55.6769 & 62.222 & .605 & .727 \\
\hline VAR00004 & 55.8308 & 62.830 & .526 & .731 \\
\hline VAR00005 & 55.7077 & 64.116 & .455 & .737 \\
\hline VAR00006 & 55.9692 & 61.562 & .566 & .725 \\
\hline VAR00007 & 55.6769 & 62.222 & .605 & .727 \\
\hline VAR00008 & 55.8308 & 62.830 & .526 & .731 \\
\hline VAR00009 & 55.9692 & 61.562 & .566 & .725 \\
\hline VAR00010 & 55.6769 & 62.222 & .605 & .727 \\
\hline VAR00011 & 29.3692 & 17.237 & 1.000 & .806 \\
\hline
\end{tabular}

Sumber : Hasil Pengolahan Data dengan SPSS Versi 25 For Windows

Untuk mencari nilai $r$ tabel dengan $\mathrm{df}=\mathrm{n}-\mathrm{k}$ atau $\mathrm{df}=65-10=55$ dan tingkat signifikan $5 \%$ maka diperoleh nilai $r$ tabel 0,2018 . Sehingga untuk melihat $r_{\text {hasil }}$ dapat dilihat pada tabel uji validitas karir $\left(\mathrm{X}_{1}\right)$ untuk lebih jelas dapat dilihat pada tabel dibawah ini.

Tabel 2. Uji Validitas Variabel Karir $\left(\mathrm{X}_{1}\right)$

\begin{tabular}{llll}
\hline Pertanyaan & \multicolumn{3}{c}{ Kepemimpinan } \\
& rhitung & $\mathbf{r}_{\text {tabel }}$ & Keterangan \\
\hline Pertanyaan 1 & 0.455 & 0.2018 & Valid \\
& & & \\
\hline Pertanyaan 2 & 0.566 & 0.2018 & Valid \\
\hline Pertanyaan 3 & 0.605 & 0.2018 & Valid \\
\hline Pertanyaan 4 & 0.526 & 0.2018 & Valid \\
\hline
\end{tabular}




\begin{tabular}{llll}
\hline Pertanyaan & \multicolumn{2}{l}{ Kepemimpinan } \\
& rhitung $_{\text {rtabel }}$ & Keterangan \\
\hline Pertanyaan 5 & 0.455 & 0.2018 & Valid \\
& & & \\
\hline Pertanyaan 6 & 0.566 & 0.2018 & Valid \\
\hline Pertanyaan 7 & 0.605 & 0.2018 & Valid \\
\hline Pertanyaan 8 & 0.526 & 0.2018 & Valid \\
\hline Pertanyaan 9 & 0.566 & 0.2018 & Valid \\
\hline Pertanyaan 10 & 0.605 & 0.2018 & Valid \\
\hline
\end{tabular}

Tabel 3. Reliability Statistics

\begin{tabular}{ll}
$\begin{array}{l}\text { Cronbach's } \\
\text { Alpa }\end{array}$ & N Of Items \\
\hline .750 & 11 \\
\hline
\end{tabular}

Dari hasil perhitungan terlihat bahwa 10 butir pertanyaan valid sebagai hasil dari uji validitas dan hasil cronbach's alpha akan menunjukkan nilai corrected sebesar 0.750 $>0.2018$, maka dapat dikatakan bahwa data valid dan reliabel.

\section{Variabel Lingkungan Kerja $\left(X_{2}\right)$}

Untuk mengetahui hasil analisis variabel Lingkungan Kerja $\left(\boldsymbol{X}_{2}\right)$ dengan rnenggunakan Komputer program Statistical Product and Service Solution (SPSS) Versi 25 for Windows input data dengan jumlah soal sebanyak 10 pernyataan, setelah itu dilakukan analisis yang sesuai sehingga menghasilkan output untuk lebih jelas lihat tabel berikut ini.

Tabel 4. Item Total Statistics

\begin{tabular}{|c|c|c|c|c|}
\hline & & Scale & $\begin{array}{l}\text { Correct } \\
\text { ed }\end{array}$ & $\begin{array}{l}\text { Cronba } \\
\text { ch's }\end{array}$ \\
\hline & $\begin{array}{l}\text { Scale } \\
\text { Mean if }\end{array}$ & $\begin{array}{l}\text { Variance } \\
\text { if }\end{array}$ & $\begin{array}{l}\text { Item- } \\
\text { Total }\end{array}$ & $\begin{array}{l}\text { Alpha } \\
\text { if Item }\end{array}$ \\
\hline & $\begin{array}{l}\text { Item } \\
\text { Deleted }\end{array}$ & $\begin{array}{l}\text { Item } \\
\text { Deleted }\end{array}$ & $\begin{array}{l}\text { Correla } \\
\text { tion }\end{array}$ & Deleted \\
\hline VAR00001 & 63.7231 & 39.422 & .258 & .708 \\
\hline VAR00002 & 64.0154 & 38.109 & .321 & .700 \\
\hline VAR00003 & 63.6462 & 37.076 & .484 & .687 \\
\hline VAR00004 & 63.6769 & 35.628 & .548 & .676 \\
\hline VAR00005 & 63.7231 & 39.422 & .258 & .708 \\
\hline VAR00006 & 64.0154 & 38,109 & .321 & .700 \\
\hline VAR00007 & 63.6462 & 37.076 & .484 & .687 \\
\hline VAR00008 & 63.6769 & 35.628 & .548 & .676 \\
\hline VAR00009 & 63.6769 & 35.628 & .548 & .676 \\
\hline VAR00010 & 63.7231 & 39.422 & .258 & .708 \\
\hline VAR00011 & 33.5538 & 10.313 & 1.000 & .655 \\
\hline
\end{tabular}

Sumber : Hasil Pengolahan Data dengan SPSS Versi 25 for windows. 
Untuk mencari nilai $r$ tabel dengan $\mathrm{df}=\mathrm{n}-\mathrm{k}$ atau $\mathrm{df}=65-10=55$ dan tingkat signifikan 5\% maka diperoleh nilai $r_{\text {tabel }}$ 0,2018 Sehingga untuk melihat $r_{\text {hasii }}$ dapat dilihat pada tabel uji validitas Lingkungan Kerja $\left(\mathrm{X}_{2}\right)$ Untuk lebih jelas dapat dilihat pada tabel dibawah ini.

\begin{tabular}{lccc} 
Tabel 5. Uji Validitas Lingkungan Kerja $\left(\mathrm{X}_{2}\right)$ \\
\hline Pertanyaan & \multicolumn{3}{c}{ Motivasi } \\
\cline { 2 - 4 } & rhitung & r $_{\text {tabel }}$ & Ket. \\
\hline Pertanyaan 1 & 0.258 & 0,2018 & Valid \\
\hline Pertanyaan 2 & 0.321 & 0,2018 & Valid \\
\hline Pertanyaan 3 & 0.484 & 0,2018 & Valid \\
\hline Pertanyaan 4 & 0.548 & 0,2018 & Valid \\
\hline Pertanyaan 5 & 0.258 & 0,2018 & Valid \\
\hline Pertanyaan 6 & 0.321 & 0,2018 & Valid \\
\hline Pertanyaan 7 & 0.484 & 0,2018 & Valid \\
\hline Pertanyaan 8 & 0.548 & 0,2018 & Valid \\
\hline Pertanyaan 9 & 0.548 & 0,2018 & Valid \\
\hline Pertanyaan 10 & 0.258 & 0,2018 & Valid \\
\hline & & &
\end{tabular}

Tabel 6. Reliability Statistics

Cronbach's N Of Items

Alpa

.712

11

Dari hasil perhitungan terlihat bahwa 10 butir pertanyaan valid sebagai hasil dari uji validitas dan hasil cronbach's alpha akan menunjukkan nilai corrected sebesar 0.712 $>0.2018$, maka dapat dikatakan bahwa data valid dan reliabel.
3. Variabel Motivasi $\left(X_{3}\right)$

Untuk mengetahui hasil analisis variabel Motivasi $\left(X_{3}\right)$ dengan menggunakan Komputer program Statistical Product and Service Solution (SPSS) Versi 25 for Windows input data dengan jumlah soal sebanyak 10 pernyataan, setelah itu dilakukan analisis yang sesuai sehingga menghasilkan output untuk lebih jelas lihat tabel berikut ini.

Tabel 7. Item Total Statistics

\begin{tabular}{|c|c|c|c|c|}
\hline & $\begin{array}{l}\text { Scale } \\
\text { Mean if } \\
\text { Item } \\
\text { Deleted }\end{array}$ & $\begin{array}{l}\text { Scale } \\
\text { Variance } \\
\text { if } \\
\text { Item } \\
\text { Deleted }\end{array}$ & $\begin{array}{l}\text { Corrected } \\
\text { Item-Total } \\
\text { Correlatio } \\
\text { n }\end{array}$ & $\begin{array}{l}\text { Cronbach's } \\
\text { Alpha if } \\
\text { Item } \\
\text { Deleted }\end{array}$ \\
\hline VAR00001 & 60.4462 & 46.626 & .248 & 704 \\
\hline VAR00002 & 60.5231 & 45.347 & .302 & .698 \\
\hline VAR00003 & 60.2154 & 44.672 & .499 & .684 \\
\hline VAR00004 & 60.3077 & 44.216 & .461 & .683 \\
\hline VAR00005 & 60.2923 & 46.616 & .337 & .699 \\
\hline VAR00006 & 60.5692 & 45.030 & .452 & .687 \\
\hline VAR00007 & 60.1692 & 45.018 & .495 & .686 \\
\hline
\end{tabular}




\begin{tabular}{|c|c|c|c|c|}
\hline & $\begin{array}{l}\text { Scale } \\
\text { Mean if } \\
\text { Item } \\
\text { Deleted }\end{array}$ & $\begin{array}{l}\quad \text { Scale } \\
\text { Variance } \\
\text { if } \\
\text { Item } \\
\text { Deleted }\end{array}$ & $\begin{array}{l}\begin{array}{l}\text { Corrected } \\
\text { Item-Total }\end{array} \\
\text { Correlatio } \\
\text { n }\end{array}$ & $\begin{array}{l}\text { Cronbach's } \\
\text { Alpha if } \\
\text { Item } \\
\text { Deleted }\end{array}$ \\
\hline VAR00008 & 60.8308 & 44.549 & .442 & .686 \\
\hline VAR00009 & 60.5385 & 45.784 & .385 & .694 \\
\hline VAR00010 & 60.3077 & 44.216 & .461 & .683 \\
\hline VAR00011 & 31.8000 & 12413 & 1.000 & .643 \\
\hline
\end{tabular}

Sumber : Hasil Pengolahan Data dengan SPSS Versi 25 For Windows.

Untuk mencari nilai $r_{\text {tabel }}$ dengan $\mathrm{df}=$ $n-k$ atau $d f=65-10=55$ dan tingkat signifikan $5 \%$ maka diperoleh nilai rtabel 0,2018 Sehingga untuk melihat rhasil dapat dilihat pada tabel uji validitas Motivasi $\left(\mathrm{X}_{3}\right)$ Untuk lebih jelas dapat dilihat pada tabel dibawah ini.

Tabel 8. Uji Validitas Variabel Motivasi $\left(\mathrm{X}_{3}\right)$

\begin{tabular}{lccl}
\hline Pertanyaan & \multicolumn{3}{c}{ Motivasi } \\
\cline { 2 - 4 } & rhitung & $\boldsymbol{r}_{\text {tabel }}$ & Ket. \\
\hline Pertanyaan 1 & 0.248 & 0,2018 & Valid \\
\hline Pertanyaan 2 & 0.302 & 0,2018 & Valid \\
\hline Pertanyaan 3 & 0.499 & 0,2018 & Valid \\
\hline Pertanyaan 4 & 0.461 & 0,2018 & Valid \\
\hline Pertanyaan 5 & 0.337 & 0,2018 & Valid \\
\hline Pertanyaan 6 & 0.452 & 0,2018 & Valid \\
\hline Pertanyaan 7 & 0.495 & 0,2018 & Valid \\
\hline Pertanyaan 8 & 0.442 & 0,2018 & Valid \\
\hline Pertanyaan 9 & 0.385 & 0,2018 & Valid \\
\hline Pertanyaan 10 & 0.461 & 0,2018 & Valid \\
\hline
\end{tabular}

Tabel 9. Realibility Statistics

Cronbach's N Of Items

Alpa

$.709 \quad 11$

Dari hasil perhitungan terlihat bahwa 10 butir pertanyaan valid sebagai hasil lari uji validitas dan hasil cronbach alph menunjukkan nilai correted sebesar .709 > 0.2018 , maka dapat dikatakan bahwa data tersebut valid dan reliable.
4. Kepemimpinan $\left(X_{4}\right)$

Untuk mengetahui hasil analisis variabel Kepemimpinan $\left(X_{4}\right)$ dengan rnenggunakan Komputer program Statistical Product and Service Solution (SPSS) Versi 25 for Windows input data dengan jumlah soal sebanyak 10 pernyataan, setelah itu dilakukan analisis sehingga menghasilkan output untuk lebih jelas lihat tabel berikut ini. 
Tabel 10. Item Total Statistics

\begin{tabular}{lllll}
\hline & $\begin{array}{l}\text { Scale } \\
\text { Mean if } \\
\text { Item } \\
\text { Deleted }\end{array}$ & $\begin{array}{l}\text { Scale } \\
\text { Variance if } \\
\text { Item } \\
\text { Deleted }\end{array}$ & $\begin{array}{l}\text { Corrected } \\
\text { Item-Total } \\
\text { Correlatio } \\
\mathrm{n}\end{array}$ & $\begin{array}{l}\text { Cronbach's } \\
\text { Alpha } \\
\text { If Item } \\
\text { Deleted }\end{array}$ \\
\hline VAR00001 & 68.5385 & 117.784 & .844 & .747 \\
\hline VAR00002 & 69.2154 & 116.359 & .862 & .743 \\
\hline VAR00003 & 68.3538 & 122.451 & .696 & .759 \\
\hline VAR00004 & 68.3692 & 121.362 & .791 & .756 \\
\hline VAR00005 & 68.6769 & 124.472 & .606 & .764 \\
\hline VAR00006 & 68.3538 & 128.607 & .407 & .774 \\
\hline VAR00007 & 68.4769 & 124.972 & .624 & .765 \\
\hline VAR00008 & 68.5077 & 116.379 & .870 & .743 \\
\hline VAR00009 & 68.2462 & 118.532 & .744 & .750 \\
\hline VAR00010 & 68.7231 & 116.828 & .740 & .747 \\
\hline VAR00011 & 36.0769 & 33.385 & 1.000 & .915 \\
\hline
\end{tabular}

Sumber : Hasil Pengolahan Data dengan SPSS Versi 25 For Windows.

Untuk mencari nilai $r$ tabel dengan $\mathrm{df}=\mathrm{n}-\mathrm{k}$ atau $\mathrm{df}=65-10=55$ dan tingkat signifikan $5 \%$ maka diperoleh nilai $r$ tabel 0,2018 , Sehingga untuk melihat hasiL dapat dilihat pada tabel uji validitas Kepemimpinan $\left(\mathrm{X}_{4}\right)$. Untuk lebih jelas dapat dilihat pada tabel dibawah ini:

Tabel 11. Uji Validitas Variabel Kepemimpinan $\left(X_{4}\right)$

\begin{tabular}{llll}
\hline Pertanyaan & \multicolumn{3}{c}{ Disiplin } \\
\cline { 2 - 4 } & rhitung & $\mathbf{r}_{\text {tabel }}$ & Ket. \\
& & & \\
\hline Pertanyaan 1 & 0.844 & 0,2018 & Valid \\
\hline Pertanyaan 2 & 0.862 & 0,2018 & Valid \\
\hline Pertanyaan 3 & 0.696 & 0,2018 & Valid \\
\hline Pertanyaan 4 & 0.791 & 0,2018 & Valid \\
\hline Pertanyaan 5 & 0.606 & 0,2018 & Valid \\
\hline Pertanyaan 6 & 0.407 & 0,2018 & Valid \\
\hline Pertanyaan 7 & 0.624 & 0,2018 & Valid \\
\hline Pertanyaan 8 & 0.870 & 0,2018 & Valid \\
\hline Pertanyaan 9 & 0.744 & 0,2018 & Valid \\
\hline Pertanyaan 10 & 0.740 & 0,2018 & Valid \\
\hline
\end{tabular}

Tabel 12. Realibility Statistics

Cronbach's N Of Items

Alpa

.776

11

Dari hasil perhitungan terlihat bahwa terdapat 10 butir pertanyaan yang valid sebagai hasil dari uji validitas dan hasil cronbach alpha menunjukkan nilai correted sebesar $0.776>0.2018$, maka dapat dikatakan bahwa data tersebut valid dan reliabel. 
5. Kinerja $(Y)$

Untuk mengetahui hasil analisis variabel Kinerja $(Y)$ dengan rnenggunakan Komputer program Statistical Product and Service Solution (SPSS) Versi 25 for Windows input data dengan jumlah soal sebanyak 10 pernyataan, setelah itu dilakukan analisis sehingga menghasilkan output untuk lebih jelas lihat tabel berikut ini.

Tabel 13. Item Total Statistics

$\begin{array}{llll}\text { Scale } & \text { Scale } & \text { Corrected } & \text { Cronbach's } \\ \text { Mean if } & \text { Variance } & \text { Item Total } & \text { Alpha if } \\ \text { Item } & \text { if Item } & \text { Correlation } & \text { Item } \\ \text { Deleted } & \text { Deleted } & & \text { Deleted }\end{array}$

\begin{tabular}{lllll}
\hline VAR00001 & 60.0923 & 40.148 & .325 & .696 \\
\hline VAR00002 & 60.3692 & 38.862 & .423 & .686 \\
\hline VAR00003 & 59.9385 & 38.090 & .555 & .676 \\
\hline VAR00004 & 60.3692 & 38.862 & .423 & .686 \\
\hline VAR00005 & 59.9846 & 37.422 & .501 & .675 \\
\hline VAR00006 & 60.3231 & 39.847 & .311 & .696 \\
\hline VAR00007 & 60.4769 & 39.503 & .340 & .693 \\
\hline VAR00008 & 60.6154 & 38.365 & .412 & .684 \\
\hline VAR00010 & 59.9846 & 37.422 & .501 & .711 \\
\hline VAR00011 & 31.6923 & 10716 & 1.000 & .634
\end{tabular}

Sumber : Hasil Pengolahan Data dengan SPSS Versi 25 for Windows

Untuk mencari nilai $r_{\text {tabel }}$ dengan $\mathrm{df}=\mathrm{n}-\mathrm{k}$ atau $\mathrm{df}=65-10=55$ dan tingkat signifikan 5\% maka diperoleh nilai $r_{\text {tabel }}$ 0,2018 Sehingga untuk melihat $r_{\text {hasil }}$ dapat dilihat pada tabel uji validitas Kinerja $(\mathrm{Y})$ Untuk lebih jelas dapat dilihat pada tabel dibawah ini:

Tabel 14. UJI VALIDITAS VARIABEL KINERJA (Y)

\begin{tabular}{llll}
\hline Pertanyaan & Disiplin & & \\
& rhitung & rtabel & Ket. \\
& & & \\
\hline Pertanyaan 1 & 0.325 & 0,2018 & Valid \\
\hline Pertanyaan 2 & 0.423 & 0,2018 & Valid \\
\hline Pertanyaan 3 & 0.555 & 0,2018 & Valid \\
\hline Pertanyaan 4 & 0.423 & 0,2018 & Valid \\
\hline Pertanyaan 5 & 0.501 & 0,2018 & Valid \\
\hline Pertanyaan 6 & 0.311 & 0,2018 & Valid \\
\hline Pertanyaan 7 & 0.340 & 0,2018 & Valid \\
\hline Pertanyaan 8 & 0.412 & 0,2018 & Valid \\
\hline Pertanyaan 9 & 0.118 & 0,2018 & Valid \\
\hline Pertanyaan 10 & 0.501 & 0,2018 & Valid
\end{tabular}


Tabel 15. Reliability Statistics

\begin{tabular}{rl}
$\begin{array}{l}\text { Cronbach's } \\
\text { Alpha }\end{array}$ & $\begin{array}{l}\mathbf{N} \\
\text { Items }\end{array}$ \\
\hline .707 & 11
\end{tabular}

Dari hasil perhitungan terlihat bahwa terdapat 10 butir pertanyaan yang valid sebagai hasil dari uji validitas dan hasil cronbach alpha menunjukkan nilai correted sebesar $0.707>0.2018$, maka dapat dikatakan bahwa data tersebut valid dan reliabel.

\section{Analisis Data Statistik \\ Analisis Koefisien Korelasi}

Tujuan analisis koefisien korelasi dimasud untuk mengetahui tingkat pengaruh dan signifikan hubungan antara variabel independen $(X)$ terhadap variabel depeden $(Y)$ secara simultan (bersama-sama) adapun hasilnya lihat tabel model Summary sebagai berikut:

\begin{tabular}{lllll}
\multicolumn{5}{c}{ Tabel 16. Model Summary } \\
\hline Model & $\mathbf{R}$ & $\begin{array}{l}\mathbf{R} \\
\text { Square }\end{array}$ & $\begin{array}{l}\text { Adjusted } \\
\text { R Square }\end{array}$ & $\begin{array}{l}\text { Std. Error } \\
\text { of } \\
\text { the } \\
\text { Estimate }\end{array}$ \\
\hline 1 & $.934^{\mathrm{a}}$ & 12 & $i 3$ & $! 1127$
\end{tabular}

a- Predictors: (Constant), VAR00004, VAR00002, VAR00001, VAR00003

Dari perhitungan koefisien korelasi pada tabel 4.16, nilai koefisien korelasi ( $\mathrm{R}$ ) antara variabel independen Karir $\left(X_{1}\right)$, Lingkungan Kerja $\left(X_{2}\right)$, Motivasi $\left(X_{3}\right)$ dan Kepemimpinan $\left(X_{4}\right)$ dengan variabel dependen Kinerja Pegawai $(Y)$ dengan nilai sebesar 0,934 . Karena nilainya tersebut hampir mendekati 1 , maka antara variabel independen Karir $\left(\mathrm{X}_{1}\right) \mathrm{t}$ Lingkungan Kerja $\left(X_{2}\right)$, Motivasi $\left(X_{3}\right)$ dan Kepemimpinan $\left(X_{4}\right)$, dengan variabel dependen Kinerja Pegawai (Y) mempunyai hubungan kuat atau sempurna. Jadi koefisien determinasi diperoleh nilai $R^{2}$ sebesar $87,2 \%$. Berarti hal ini menunjukkan bahwa variabel independen Karir
$\left(X_{1}\right)$, Lingkungan Kerja $\left(X_{2}\right)$, Motivasi $\left(X_{3}\right)$ dan Kepemimpinan $\left(X_{4}\right)$ dengan variabel dependen Kinerja Pegawai ( $\mathrm{Y}$ ) mempunyai pengaruh sebesar $87,2 \%$ dan sisanya sebesar $12,8 \%$ dipengaruhi oleh faktor yang lainnya.

\section{Uji Anova}

Dari hasil analisis secara bersama-sama variabel Karir $\left(X_{1}\right)$, Lingkungan Kerja $\left(X_{2}\right)$, Motivasi $\left(X_{3}\right)$, dan Kepemimpinan $\left(X_{4}\right)$ dengan Kinerja Pegawai $(\mathrm{Y})$ rnenggunakan Komputer program Statistical Package and Service Solution (SPSS) Versi 25 for Windows yakni sebagai berikut: 
Tabel 17. UJI ANOVA

\begin{tabular}{rlrllll}
\hline Model & $\begin{array}{l}\text { Sum of } \\
\text { Square } \\
\text { s }\end{array}$ & df & $\begin{array}{l}\text { Mean } \\
\text { Square }\end{array}$ & F & Sig. \\
\hline 1 & 597.81 & 4 & 149.454 & 101.86 & $.000^{\mathrm{a}}$ \\
Regression & 5 & 60 & 1.467 & & \\
\hline Residual & 88.031 & 64 & & & \\
\hline Total & 685.84 & 64 & & & \\
& 6 & & & & \\
& & & & & \\
\end{tabular}

a- Predictors: (Constant), VAR00004, VAR00002, VAR00001, VAR00003

b- Dependent Variable: VAR00005

Hasil uji ANOVA atau $F_{\text {test }}$ di dapat $F_{\text {hitung }}$ sebesar 101.865 dimana lebih besar dari $F_{\text {tabel }}$ dengan $\mathrm{df}=64$ jadi nilai $F_{\text {tabel }}$ sebesar 2.371 dengan tingkat signifikan sebesar 0,000 karena $0,000<0,05$, maka dapat dikatakan variabel Karir $\left(X_{1}\right)$, Lingkungan Kerja $\left(X_{2}\right)$, Motivasi $\left(X_{3}\right)$ dan Kepemimpinan $\left(X_{4}\right)$ terhadap Kinerja Pegawai $(\mathrm{Y})$ berpengaruh.
Uji t

Untuk mengetahui apakah masingmasing variabel Karir $\left(X_{1}\right)$, Lingkungan Kerja $\left(X_{2}\right)$, Motivasi $\left(X_{3}\right)$ dan Kepemimpinan $\left(X_{4}\right)$ secara parsial mempunyai hubungan bermakna terhadap Kepuasan Pegawai (Y) dilakukan pengujian $t_{\text {hitung }}$ dan $t_{\text {tabel. }}$ Uji $t$ ini dilakukan dengan cara membandingkan antara hasil thitung dengan $t_{\text {tabel }}$ yaitu memiliki nilai masing-masing sebagai berikut:

Tabel 19. Hasil Uji t

\begin{tabular}{llll}
\hline Variabel & $\begin{array}{l}\text { Standard } \\
\text { Error }\end{array}$ & thitung & $t_{\text {tabel }}$ \\
\hline Karir $\left(\mathrm{X}_{1}\right)$, & 0,048 & 5.027 & 1.671 \\
\hline $\begin{array}{l}\text { Lingkungan } \\
\text { Kerja }\left(\mathrm{X}_{2}\right)\end{array}$ & 0,065 & 8.841 & 1.671 \\
\hline Motivasi $\left(\mathbf{X}_{3}\right)$ & 0,073 & 3.053 & 1.671 \\
\hline $\begin{array}{l}\text { Kepemimpinan } \\
\left(\mathrm{X}_{4}\right)\end{array}$ & 0,027 & 1.271 & 1.671 \\
\hline
\end{tabular}

Atas dasar uji t tersebut di atas, terbukti bahwa variabel Karir $\left(\mathrm{X}_{1}\right)$, secara parsial mempunyai pengaruh terhadap Kinerja Pegawai (Y) pada tarap nyata. Dengan demikian dapat dinyatakan bahwa $\mathrm{H}_{\mathrm{o}}$ ditolak $\mathrm{H}_{\mathrm{a}}$ diterima.

Adapun perumusan Hipotesisnya adalah :

a. $H_{0-}=p=0$ : Menyatakan tidak terdapat pengaruh yang berarti antara Variabel Karir $\left(X_{1}\right)$, Lingkungan Kerja $\left(X_{2}\right)$, Motivasi $\left(X_{3}\right)$ dan Kepemimpinan $\left(X_{4}\right)$ dengan variabel Kinerja pegawai $(\mathrm{Y})$ b. $\mathrm{H}_{\mathrm{a}-}=\mathrm{p}>0$ : Menyatakan terdapat pengaruh yang berarti antara Variabel Karir $\left(\mathrm{X}_{1}\right)$, Lingkungan Kerja $\left(X_{2}\right), \quad$ Motivasi $\left(X_{3}\right)$ dan Kepemimpinan $\left(X_{4}\right)$ dengan variabel Kinerja pegawai $(\mathrm{Y})$

\section{HASIL DAN PEMBAHASAN}

Pengaruh Karir Terhadap Kinerja pegawai.

Hasil uji hipotesis menunjukan bahwa Karir memberikan kontribusi positif signifikan terhadap kinerja, artinya semakin meningkat karir atau kedudukan dalam hirarki formal yang 
sudah ditetapkan dalam suatu organisasi, semakin tinggi kinerja pegawai. Dalam paradigma tradisional, pengembangan karir sering dianggap sinonim dengan persiapan untuk mobilisasi ke jenjang lebih tinggi akan mendukung efektivitas pegawai dalam peningkatan kinerja untuk mencapaian tujuan organisasi.

\section{Pengaruh Lingkungan Kerja terhadap Kinerja pegawai.}

Berdasarkan hasil uji hipotesis menunjukan bahwa lingkungan kerja memberikan kontribusi positif yang signifikan terhadap kinerja, artinya semakin tinggi tingkat kenyamanan ruang kerja akan membuat pegawai semakin menyukai pekerjaannya dan bertahan lama dalam ruang kerja. Ruangan kerja merupakan tempat pegawai menghabiskan sebagian besar waktu setiap harinya, karena itulah penting sekali menciptakan lingkungan kerja yang sehat agar dapat membuat para pegawai merasa nyaman. Namun tidak hanya itu, lingkungan kerja yang sehat ternyata juga memiliki manfaat besar bagi organisasi dalam mendukung efektivitas pegawai dalam meningkatkan kinerja .

\section{Pengaruh Motivasi terhadap kinerja pegawai.}

Berdasarkan hasil uji hipotesis menunjukan bahwa motivasi kerja memberikan kontribusi positif signifikan terhadap kinerja pegawai artinya semakin tinggi moivasi kerja pegawai maka semakin tinggi kinerja pegawai. Begitu pula sebaliknya semakin rendah motivasi kerja pegawai maka akan rendah kinerja pegawai. Pimpinan organisasi selalu meberikan masukan,arahan dan semangat kepada pegawai untuk meningkatkan kinerja, diiringi dengan peningkatan kinerja pegawai. Hal ini sesuai dengan pendapat Safwan, dkk (2014) yang menjelaskan bahwa motivasi berpengaruh terhadap kinerja pengelolaan keuangan. Motivasi merupakan dorongan seseorang untuk melakukan sesuatu atau tindakan yang mengarah pada tujuan. Semakin besar motivasi yang diberikan organisasi kepada pegawai akan meningkatkan kinerja dari pegawai tersebut hal ini tentu juga akan membuat semakin produktifnya kerja dari organisasi.

Pengaruh Kepemimpinan terhadap Kinerja. Berdasarkan hasil uji hipotesis menunjukan bahwa kepemimpinan memberikan kontribusi positif tidak signifikan terhadap kinerja pegawai artinya Sistem kepemimpinan dalam suatu organisasi yang telah berjalan dengan baik tidak terlalu signifikan akan keberadaan seorang pimpinan yang setiap hari harus ada ditempat karena menurut Syafi"ie (2003) kepemimpinan diartikan sebagai sebuah seni, hal ini merujuk kepada pendapat George R. Terry bahwa "Art is personal creative power plus skill in performane" (maksudnya adalah seni yaitu kekuatan pribadi seseorang yang kreatif ditambah dengan keahlian yang bersangkutan dalam menampilkan tugas pekerjaanya).

Kepemimpinan suatu unit organisasi dapat dianalogikan sebagai sebuah seni yang maksudnya adalah seorang pimpinan organisasi dengan keahliannya mampu menyelenggarakan jalannya organisasi secara indah dan baik. Dari kata memimpin ini terbentuklah kepemimpinan, yaitu kemampuan menggerakan dan mengarahkan orang-orang, ini berarti telah berlangsung suatu hubungan manusia (human relation) yaitu antara yang menggerakan dan mengarahkan (ruller) dengan yang digerakan atau diarahkan (follower).

\section{PENUTUP}

Dari hasil analisis yang telah dilakukan, maka dapat ditarik kesimpulan antara lain sebagai berikut; Jenjang karir, suasana lingkungan kerja serta motivasi dari pimpinan sangat berpengaruh terhadap kinerja para pegawai Pusat Informasi Pengawasan Badan Pengawasan Keuangan dan Pembangunan. Karir adalah jalur umum yang dipilih seseorang untuk diikuti sepanjang kehidupan kerjanya. Sebuah karir adalah urutan posisi-posisi terkait 
pekerjaan yang diduduki seseorang sepanjang masa hidupnya. Lingkungan Kerja adalah kehidupan sosial, psikologi dan fisik dalam suatu unit kerja atau perusahaan yang berpengaruh terhadap pekerja dalam melaksanakan tugasnya dimana para perkerja mendapatkan rasa aman dan nyaman dalam bekerja.

Motivasi dan Kepemimpinan adalah suatu keahlian dalam mengarahkan karyawan dan organisasi agar mau bekerja secara berhasil, sehingga keinginan para karyawan dan tujuan organisasi sekaligus tercapai.

Agar karyawan dapat bekerja lebih optimal, maka pimpinan harus memberikan motivasi kepada pegawainya, motivasi kepada pegawai dapat dilakukan dengan berbagai cara, yaitu adanya motivasi positif seperti pemberian hadiah, penghargaan maupun kenaikan pangkat disamping ada juga motivasi yang sifatnya negatif, seperti pemberian peringatan atau hukuman bagi pegawai yang melakukan kesalahan ,sehingga berdampak pada peningkatan kinerja.

Berdasarkan kesimpulan yang telah diuraikan diatas, penulis memberikan saransaran yang diharapkan berguna bagi kemajuan organisasi.

Adapun saran-saran yang dapat dikemukakan adalah sebagai berikut :

1. Unit kerja Pusat Informasi Pengawasan Badan Pengawasan Keuangan dan Pembangunan perlu adanya langkahlangkah baru guna menjadikan Jenjang karir,Lingkungan Kerja,Motivasi dan Kepemimpinan yang sudah menghasilkan nilai yang baik, bila perlu ditingkatkan dimasa mendatang serta harus semakin maju dan tanggap terhadap perubahan dimana Jenjang Karir,Lingkungan Kerja, Motivasi dan Kepemimpinan dapat mempengaruhi Peningkatan Kinerja Pegawai.
2. Unit Kerja Pusat Informasi Pengawasan Badan Pengawasan Keuangan dan Pembangunan harus memberikan faktorfaktor penunjang dalam pencapaian tujuan salah satunya dengan penambahan fasilitasfasilitas meningkatkan kinerja para pegawainya dapat memotivasi pegawai dengan memberikan insentif, bonus dan kesempatan untuk mengembangkan karir. Memberikan perhatian terhadap para pegawai secara keseluruhan diharapkan terus menjadi kebiasaan para pimpinan diorganisasi, sehinga kinerja pegawai Pusat Informasi Pengawasan Badan Pengawasan Keuangan dan Pembangunan dapat lebih ditingkatkan sebagaimana yang diharapkan pimpinan dimasa mendatang.

\section{REFERENSI}

Dessler, G. (2015). Manajemen Sumber Daya Manusia. Jakarta: Salemba Empat.

Hasibuan, M. (2013). Manajemen Sumber Daya Manusia. Jakarta: Bumi Aksara.

Mangkunegara , Anwar P. (2008). Evaluasi Kinerja SDM. Bandung: Refika Aditama.

Notoadmojo, S. (2009). Pengembangan Sumber Daya Manusia. Jakarta: Rineka Cipta.

Priansa, Doni. (2013). Manajemen Perkantoran Efektif, Efesien dan Profesional. Bandung: Alfabeta.

Sastrodadiwiryo, S. 2005. Manajemen Tenaga Kerja Indonesia. Jakarta: Sinar Grafika Offset.

Sedarmayanti. (2010). Manajemen Sumber Daya Manusia Reformasi Birokrasi dan Manajemen Pegawai Negeri Sipil. Bandung: Refika Aditama,

Thoha, M. (2014). Manajemen Kepegawaian Sipil Di Indonesia. Jakarta: Prenadamedia Group.

Yusi, Syahirman dan Idris, U. (2010). Statistika untuk Ekonomi dan Penelitian. Palembang: Citabooks Indonesia. 
